Włodzimierz Plewczyński*

\title{
HISTORYCZNE UWARUNKOWANIA POWSTANIA I ROZWOJU RYNKÓW TELEFONII KOMÓRKOWEJ W XX I XXI WIEKU
}

\section{Wprowadzenie}

Rynek telefonii komórkowej do tej pory dość rzadko bywa przedmiotem opisu i analiz ekonomicznych. Polska literatura na jego temat wciąz jest stosunkowo wątła. Przynajmniej częściowo może to wynikaćz wciąż silnie zakorzenionego przekonania, że rynek ten - pomimo ćwierćwiecza obecności w naszym kraju - stanowi w dalszym ciągu relatywnie nowy rynek, włączony, a zarazem budujący przestrzeń gospodarki globalnej w XXIw. W związku $z$ tym mogłaby istnieć bardzo słaba tendencja do postrzegania tego rynku w kategoriach historycznego już fenomenu, który - dla lepszego zrozumienia i dostrzeżenia jego natury - wymagałby również retrospektywnej perspektywy opisowej i analitycznej, nieograniczającej się tylko do polskich realiów.

Cel tego artykułu koncentruje się na pokazaniu najważniejszych zdaniem autora historycznych uwarunkowań powstania i wyłonienia się rynków telefonii komórkowej na świecie. Przywołane i rozważone zostały dwie grupy fundamentalnych uwarunkowań, które w największym stopniu mogłyby wyjaśniać szybką ekspansję telefonii komórkowej oraz szeroki zakres i tempo innowacyjności, w dużej mierze decydujących nie tylko o uczynieniu z telefonii komórkowej rynkowego, globalnego „produktu numer jeden” w gospodarce i społeczeństwie XXI w., ale również o przeobrażeniach, jakie dzięki telefonii mobilnej zaszły w strukturach i funkcjonowaniu gospodarki światowej jako całości. Do tych historycznych i powiązanych ze sobą uwarunkowań zaliczono $z$ jednej strony uwarunkowania technologiczne, $z$ drugiej zaś uwarunkowania polityczno-prawne, przy czym oba te typy oddziaływań należałoby traktować jako ściśle ze sobą powiązane. Rynek ten od początku formował się bowiem jako specyficzna przestrzeń szeregu dynamicznych relacji, zachodzących pomiędzy technologią, polityką, prawem, a nawet stosunkami międzynarodowymi w obszarze

* Doktorant Kolegium Ekonomiczno-Społecznego, Szkola Glówna Handlowa w Warszawie. 
polityki i gospodarki. W związku z tym perspektywa historyczna pozwala rzucić więcej światła na sposób, w jaki ewolucja technologii umieszczona w zmieniającym się kontekście polityczno-prawnym określała naturę tego nowego rynku, dynamizując ogólniejsze procesy globalizacji i integracji gospodarczej świata. Pozwala ona również na lepsze uświadomienie złożoności i w dużej mierze interdyscyplinarności tej problematyki, w której ogromną rolę odgrywają czynniki tradycyjnie umieszczane poza obszarem ekonomii sensu stricto.

\section{Uwarunkowania technologiczne}

Jakkolwiek telefonia komórkowa jest uważana za stosunkowo nowy wynalazek, początki tej technologii sięgają pierwszej dekady XXw. Za jej pioniera często uznaje się amerykańską firmę Oakland Transcontinental Aerial Telephone and Power Company, która już w 1908 r. zapowiadała wprowadzenie na rynek urządzenia umożliwiającego bezprzewodowy przekaz głosowy na odległość . Jednakże urządzenie to prawdopodobnie nie było w stanie spełnić przypisywanych mu funkcji, wobec czego nigdy nie zostało zaprezentowane szerszej publiczności². Prekursorskie urządzenia, które można uznać za poprzedników telefonów komórkowych we współczesnym tego słowa znaczeniu, zostały z powodzeniem zastosowane dopiero w Niemczech po I wojnie światowej, gdzie zbudowano pierwsze systemy głosowych połączeń bezprzewodowych, bazujących na technologii radiowej. Systemy te wykorzystywano początkowo w pociągach wojskowych. W 1925 r., po założeniu spółki Zugtelephonie A.G., usługi bezprzewodowych połączeń telefonicznych zostały zaoferowane podróżnym niektórych pociągów Deutsche Reichsbahn ${ }^{3}$.

W Stanach Zjednoczonych łączność bezprzewodowa oparta na technologii radiowej pojawiła się w latach 40. ubiegłego wieku za sprawą narodowego operatora American Telephone and Telegraph (AT\&T). Korporacja ta wprowadziła na rynek zaprojektowane i wyprodukowane przez siebie telefony bezprzewodowe $z$ przeznaczeniem do instalacji w samochodach. W czerwcu 1946 r., po uzyskaniu przydziału częstotliwości radiowych z Federalnej Komisji Łączności, pierwsza taka komercyjna usługa została uruchomiona w St. Louis w stanie Missouri. W kolejnych latach zaś

1 A. Sathi, Engaging Customers Using Big Data. How Marketing Analytics in Transforming Business, Palgrave Macmillan, New York 2014, s. 24.

2 S.R. Ellis, Mobile Standards, [w:] Mobile Devices. Tools and technologies, red. L. Collins, S.R. Ellis, CRC Press, Boca Raton 2015, s. 163.

3 Ibidem, s. 166. 
zbudowano infrastrukturę dla stu następnych miejscowości i autostrad ${ }^{4}$. Przy okazji warto odnotować, ze w latach 40. i 50. telefonia komórkowa była kojarzona raczej tylko $z$ telefonami montowanymi w pojazdach.

Niemniej jednak telefonia komórkowa w znaczeniu zbliżonym do współczesnego pojawia się po raz pierwszy w latach 50. ubiegłego wieku w Szwecji. W $1956 \mathrm{r}$. szwedzka firma Ericsson zademonstrowała nowatorski model telefonu wzorowanego na przenośnej radiostacji używanej na frontach II wojny światowej, gdzie zastosowano technologię fal radiowych. Urządzenie to było oparte na w pełni automatycznym systemie MTA (szwedz. Mobilelefonisystem A, ang. Mobil Telephone System A), niewymagającym ręcznej kontroli w stacjach bazowych. Od tego roku w Szwecji ruszyła pierwsza sieć telefonii komórkowej wykorzystująca ten system, obsługiwany przez państwowego operatora Televerket ${ }^{5}$. W latach 60 . Ericsson wprowadził na rynek nową, zaktualizowaną wersję systemu MTB, pozwalającą na poszerzenie zasięgu sieci mobilnej oraz zmniejszył wagę swego telefonu do około $10 \mathrm{~kg}^{6}$.

Mimo że telefonia komórkowa była w tym czasie raczej tylko ekskluzywną nowinką i produktem zasadniczo niestwarzającym większych szans na otwarcie masowego rynku, niewątpliwie przyciągała uwagę rządów, które zaczęły dostrzegać w niej spore możliwości tworzenia potencjalnych udogodnień w obszarze wymiany dóbr i przemieszczania się ludzi. Na przełomie szóstej i siódmej dekady XXw. w Szwecji pojawił się pomysł stworzenia swego rodzaju transnarodowej sieci telekomunikacyjnej, która mogłaby obejmować wszystkie kraje skandynawskie ${ }^{7}$. Pomysł ten wynikał w dużej mierze $z$ dynamicznego wzrostu przepływu ludności pomiędzy tymi krajami oraz ułatwień, jakie niosła za sobą możliwość budowy wspólnej sieci telefonii komórkowej. Szwecja była w tym okresie najbardziej wpływowym państwem w całym regionie Skandynawii oraz największym eksporterem towarów do wszystkich państw kręgu nordyckiego. Z tych względów w 1969 r. to właśnie Szwecja wystąpiła z propozycją stworzenia wspólnej, skandynawskiej sieci telekomunikacji mobilnej w oparciu o rozwiązania sprawdzone u siebie. Ponieważ propozycja ta spotkała się

4 M. Iebert, K. Pang, W. Chien-Ling, R. Sou, R. Kadiyala, $3 G$ Telecommunications: Innovative Designs of Cellular Phones, [w:] Financing Technology Innovation, red. G. Shahi, J. Greco, GBI Books, Los Angeles 2008 , s. 20

5 O. Billström, L. Cederquist, M. Ewerbring, G. Sandegren, J. Uddenfeldt, Fifty years with mobile phones. From novelty to no. 1 consumer product, „Ericsson Review” No. 3, 2006, s. 101. Warto odnotować, że telefon wyprodukowany przez Ericssona był ciężki (około $40 \mathrm{~kg}$ ) i bardzo nieporęczny w transporcie. Zostal zaprojektowany jako pokaźnych rozmiarów walizka, wyposażona w akumulatory wymagające bardzo częstego ladowania. Sieć mobilna działala tylko w dwóch największych szwedzkich miastach, wobec czego ten bardzo drogi produkt był przeznaczony raczej tylko dla armii i dużego biznesu.

6 Ibidem, s. 101.

Evolution and Standarization of Mobile Communications Technology, red. D.B. Seo, IGI Global, Hershey 2013 , s. 57. 
z entuzjastycznym przyjęciem ze strony pozostałych państw skandynawskich, powołano do życia specjalną panskandynawską grupę roboczą pod nazwą NMT (Nordic Mobile Telephone Group). Celem grupy było zbadanie możliwości budowy w pełni automatycznej i wystandaryzowanej sieci telefonii komórkowej na terenie państw wchodzących w jej skład.

Na początku lat 70. szwedzki system telefonii komórkowej MTD w zaktualizowanej wersji, obsługującej częstotliwość radiową $450 \mathrm{MHz}$, został wdrożony w Danii, Norwegii i Finlandii. Wdrożeniem tym zajmowali się tamtejsi operatorzy narodowi we współpracy $z$ przedsiębiorstwami produkującymi aparaty telefoniczne oraz przy aktywnym wsparciu rządów ${ }^{8}$. W związku $z$ tym w latach 70. Skandynawia, ze szczególnym uwzględnieniem Szwecji, stała się najbardziej zaawansowanym pod względem telefonii mobilnej regionem świata, w którym zaczął funkcjonować pierwszy ponadnarodowy system telefonii komórkowej - NMT. Ten analogowy system, inaugurujący tzw. pierwszą generację telefonii mobilnej, zainspirował powstanie innych systemów analogowych, takich jak zaprojektowany w USA system AMPS oraz opracowany w latach 80 . we Francji Radiocom $2000^{\circ}$. Skandynawski system NMT odegrał również prominent ną rolę w otwieraniu nowych europejskich rynków telefonii komórkowej po przemianach politycznych przełomu lat 80. i 90. oraz upadku Związku Radzieckiego. W początkach lat 90. to właśnie ten system był wdrażany w krajach postsocjalistycznych przez pierwszych operatorów komórkowych. W Polsce w tę pionierską rolę weszła spółka operatorska joint venture, działająca pod nazwą Polska Telefonia Komórkowa Centertel Sp. z o.o., której właścicielem był operator narodowy Telekomunikacja Polska SA, działający we współpracy z francuskim operatorem France Telecom oraz amerykańskim koncernem Ameritech International ${ }^{10}$. Usługi telefonii komórkowej w systemie analogowym wystartowały w $1992 \mathrm{r}$. i były świadczone pod marką „Idea-Centertel”.

Niemniej jednak telefonia analogowa - nawet po opracowaniu przez firmę Motorola w latach 70. zminiaturyzowanej wersji telefonu komórkowego, która przyczyniła się do upowszechnienia się na świecie standardów analogowych - była wciąz telefonią w pewien sposób elitarną i produktem dostępnym - głównie ze względu na wysoką cenę aparatów i usług telefonicznych - raczej tylko dla bardzo zamożnych klientów. Według danych Banku Światowego w 1991 r. komercyjne rynki telefonii komórkowej byly co prawda obecne już w 102 krajach świata, jednak przeciętny wskaźnik

\footnotetext{
8 Ibidem, s. 57-58.

9 O. Billström, L. Cederquist, M. Ewerbring, G. Sandegren, J. Uddenfeldt, op.cit., s. 101.

10 W. Wereda, Czynniki wplywające na rozwój rynku telefonii komórkowej w Polsce, "Zeszyty Naukowe Akademii Podlaskiej” nr 82, 2009, S. „Administracja i Zarządzanie”, s. 97.
} 
penetracji rynku w skali globalnej wynosił zaledwie $0,4 \%{ }^{11}$. W najbardziej zaawansowanej pod tym względem Szwecji wskaźnik ten osiągnął niespełna 7\%, w Stanach Zjednoczonych niecałe 3\%, z kolei w Niemczech i we Francji zaledwie 0,66\% ${ }^{12}$. Dane te pokazują, że w tym okresie trudno jest mówić o istnieniu masowego rynku telefonii komórkowej w pełnym tego słowa znaczeniu. Wydaje się bowiem, że ów masowy rynek, na którym telefon komórkowy i dostęp do usług mobilnych stały się obiektywnie osiągalne dla zwykłych obywateli, w rzeczywistości wyłonił się dopiero po wdrożeniu tzw. drugiej generacji telefonii komórkowej.

Historycznie, źródła tej technologicznej generacji również mogą zostać zlokalizowane w Europie, gdzie jeszcze w pierwszej połowie lat 80. ubiegłego wieku rozpoczęto prace nad systemem cyfrowym, opartym na wyspecjalizowanych systemach przywoławczych i trankingowych oraz postępie w obszarze komputeryzacji. Już w 1984 r. szwedzka firma Ericsson, działająca we współpracy z narodowym operatorem Televerket, zaprezentowała oficjalnie pierwszy taki eksperymentalny prototyp systemu połączeń bezprzewodowych, pracujący w technice cyfrowej. Przypisano mu nazwę Global System for Mobile Communications (GSM), z zamiarem opracowania rozwiązań, które pozwoliłyby na upowszechnienie tego systemu w Europie. W 1982 r. Europejska Konferencja Administracji, Poczty i Telekomunikacji (fr. Conférence européenne des administrations des postes et des télécommunications) rozpoczęła prace nad zdefiniowaniem ogólnoeuropejskiego systemu połączeń mobilnych dla nowych częstotliwości, przewidzianych dla systemu GSM (początkowo była to częstotliwość $900 \mathrm{MHz})^{13}$. Po kilku latach ten cyfrowy standard został po raz pierwszy wdrożony w Finlandii (1989 r.), debiutując na komercyjnym rynku fińskim w 1991 r. $^{14}$ W Polsce sieci GSM pojawiły się w $1996 \mathrm{r}$. za sprawą rozstrzygnięcia trzeciego rządowego przetargu na telefonię komórkową, w którym zwyciężył Polkomtel SA (operator sieci „Plus”) oraz Polska Telefonia Cyfrowa (operator świadczący usługi telefonii GSM pod marką „Era”). W 1998 r. częstotliwości na świadczenie usług w systemie GSM zdobył też PTK Centertel, wprowadzając na polski rynek markę „Idea”.

Początkowo zakładano, że standard GSM obejmie tylko kontynent europejski, zwłaszcza że w USA w tym samym czasie zaprojektowano konkurencyjny dla GSM system cyfrowy D-AMPS. Jednak bardzo szybko okazało się, że to właśnie GSM stanie się standardem ogólnoświatowym. W 1993 r. umowę na jego wdrożenie podpisała

11 L. Waverman, M. Meschi, M. Fuss, The Impact of Telecoms on Economic Growth in Developing Countries, ,Working Paper the Vodafone Policy" No. 3, 2005.

12 Według danych statystycznych ONZ: http://data.un.org/Data.aspx?d=MDG\&f=seriesRowID:756 [dostęp 10.04.2017].

13 O. Billström, L. Cederquist, M. Ewerbring, G. Sandegren, J. Uddenfeldt, op.cit., s. 102.

14 J.L. Burbank, J. Andrusenko, J.S. Everett, W.T.M. Kasch, Wireless Networking. Understanding Internetworking Challenges, John Wiley \& Sons, New York 2013, s. 389. 
Australia, jako pierwszy pozaeuropejski operator. W kolejnych latach GSM został zaimplementowany w USA, Rosji, Chinach, Republice Południowej Afryki, Singapurze i Hongkongu ${ }^{15}$. W sierpniu 1995 r. sygnatariuszami porozumienia w sprawie wykorzystania tego standardu technologicznego było już 138 operatorów z 77 krajów całego świata ${ }^{16}$.

System cyfrowy, inaugurujący telefonię komórkową drugiej generacji, okazał się być kluczową drogą do umasowienia technologii mobilnej jako jednego $z$ najbardziej ekspansywnych produktów na rynkach światowych przełomu XX i XXI w. Od tego momentu rozpocząl się specyficzny „boom” na telefonię komórkową, a branża ta stała się jedną $z$ najbardziej dochodowych i lukratywnych w skali całego świat ${ }^{17}$. System cyfrowy przezwycięzył bowiem szereg niedociągnięć technologii analogowej w zakresie jakości połączeń, pojemności sieci, dostępności, wagi i poręczności aparatów telefonicznych, bezpieczeństwa i w dużej mierze ceny usług telefonicznych. Rewolucyjnym osiągnięciem było przede wszystkim zaoferowanie nowej usługi komunikatów tekstowych SMS (ang. short message service), które do dzisiaj uważa się za jeden z kamieni milowych w ewolucji technologii bezprzewodowej. Dalsze doskonalenie systemu GSM prowadziło do szybkiego poszerzania funkcjonalności aparatów telefonicznych, przeistaczających się stopniowo w zminiaturyzowane gadzety z coraz lepszą grafiką i systemami zasilania. Telefony komórkowe coraz bardziej zakorzeniały się w życiu konsumenta XXI w., stając się nieodzownym urządzeniem codziennego użytku.

Telefonia komórkowa ewoluowała szczególnie wraz z rozwojem internetu. Rozwój ten zainspirował ponadnarodową współpracę firm telekomunikacyjnych, operatorów sieci telefonicznych oraz producentów telefonów i oprogramowania, której celem była modyfikacja systemu GSM pod kątem dostępu do sieci internetowej oraz wprowadzenia usługi transmisji danych ${ }^{18}$. Po raz pierwszy usługa taka została udostępniona pod koniec lat 90, kiedy wdrożono standard WAP (Wireless Aplication Protocol) pozwalający na zainstalowanie w telefonie przeglądarki internetowej. W 2000 r. pojawily się technologie: GPRS (General Packet Radio Service) oraz EDGE

15 Ibidem, s. 390.

16 P. Maskell, I. Eskelinen, I. Iannibalsson, A. Mamberg, E. Vatne, Competitiveness, Localised Learning and Regional Development. Specialization and prosperity in small open economies, Routledge, New York 2002, s. 164.

17 O ile w 1990 r. z telefonii mobilnej korzystało zaledwie $11 \mathrm{mln}$ mieszkańców świata, o tyle pięć lat później liczba ta wzrosła ośmiokrotnie, a w 2000 r. ponad 60-krotnie. Sukcesywny wzrost liczby kart SIM postępował z każdym rokiem XXIw., aby w 2007 r. po raz pierwszy osiągnąć połowę liczby mieszkańców całego globu: ITU - Key Global Telecoms Indicators: http://www.itu.int/en/ITU-D/Statistics/Pages/ default.aspx [dostęp 10.04.2017].

18 WAP - nowy wymiar telefonii komórkowej, „Magazyn Elektroniki Użytkowej” nr 7, 2000, s. 95. 
(Enhanced Data Rates for GSM Evolution), umożliwiające szybszy transfer przesyłu danych w sieciach GSM oraz nowe usługi w postaci komunikatów multimedialnych (MMS, Multimedia Messaging Service). Innowacje te zasadniczo przyczyniły się do tego, że nowe modele telefonów po $2000 \mathrm{r}$. zaczęly być produkowane z uwzględnieniem możliwości dostępu do internetu ${ }^{19}$.

Próby połączenia telefonii komórkowej $z$ internetem doprowadziły wkrótce do powstania tzw. telefonii trzeciej generacji, nazwanej w skrócie UMTS (Universal Mobile Telecommunications System). Technologia ta - dzięki zasadniczemu zwiększeniu szybkości przesyłu danych - pozwoliła na swobodne łączenie się z internetem za pomocą telefonu komórkowego. W rezultacie udało się zwiększyć pojemność sieci, a rozbudowie uległy usługi multimedialne, takie jak telewizja mobilna, wideokonferencje i wideorozmowy. Był to jednocześnie pierwszy system umożliwiający globalny zasięg lączności oraz zaawansowane usługi lokalizacyjne i nawigacyjne ${ }^{20}$. Standard ten okazał się atrakcyjny zarówno dla firm operatorskich, które znacząco zyskiwały na obniżeniu nakładów w budowę sieci telefonicznej, jak i dla finalnych klientów, którzy otrzymywali dostęp do nowych i niezwykle atrakcyjnych usług. Dopiero jednak pojawienie się na rynku nowego typu telefonu - tzw. smartfonu - będącego wielofunkcyjnym urządzeniem wyposażonym w system operacyjny i duży ekran dotykowy, wprowadziło rynek telefonii komórkowej w erę mobilnych i wygodnych połączeń $z$ internetem ${ }^{21}$.

Równolegle trwały dalsze prace nad doskonaleniem standardów telefonii komórkowej w zakresie doskonalenia możliwości przesyłu danych. W ich wyniku w 2009 r. skandynawski operator TeliaSonera wdrożył na terenie Szwecji i Norwegii pierwszą sieć działającą w nowym standardzie, zaliczanym do technologii „czwartej generacji” - LTE (Long Term Evolution) ${ }^{22}$. Rok później technologia ta pojawiała się m.in. w Polsce, gdzie jeszcze w $2010 \mathrm{r}$. zasięgiem tej sieci pokryto około 1/3 powierzchni kraju. Pozwoliła ona na znaczną redukcję kosztów transferu danych, zwiększenie liczby usług, elastyczne wykorzystywanie różnych pasm częstotliwości oraz oszczędność energii zuzywanej przez terminale ${ }^{23}$. Aktualnie zaś trwają prace nad telefonią komórkową

19 M. Karbowniczek, Nowe technologie w sieciach telefonii komórkowej, „Elektronika Praktyczna” nr 2, 2014 , s. 64

20 O. Billström, L. Cederquist, M. Ewerbring, G. Sandegren, J. Uddenfeldt, op.cit., s. 105.

21 Zaprojektowany w laboratoriach amerykańskiej firmy Aple\& Inc. przez zespół Stevéa Jobsa smartfon po raz pierwszy zostal wprowadzony na rynek w $2007 \mathrm{r}$., w blyskawicznym tempie zdobywając miliony użytkowników: M. Sarwar, T.R. Soomro, Impact of Smartphone’s on Society, „European Journal of Scientific Research" No. 2, 2013, s. 217.

22 D. Guga, Technologia GSM jako platforma usług WWW i aplikacji internetowych - właściwości rozwiazań m-commerce, „Acta Universitatis Lodziensis” nr 167, 2003, S. „Folia Oeconomica”, s. 410.

${ }^{23}$ Long Term Evolution (LTE). Kolejny krok w ewolucji systemów telefonii komórkowej, Prezes Urzędu Komunikacji Elektronicznej, Warszawa, maj 2010, s. 7. 
"piątej generacji”, w które zaangażowali się azjatyccy producenci smartfonów - Huawei i Samsung przy współpracy rządu Wielkiej Brytanii, Korei Południowej i Unii Europejskiej. Oczekuje się, że standard ten pozwoli przede wszystkim na dalsze zwielokrotnienie prędkości przesyłania danych oraz przezwycięzenie spadków wydajności sieci i trudności z przepustowością. Jego wdrożenie planowane jest na $2020 \mathrm{r}^{24}$

Ten zwięzly zarys powstania i ewolucji telefonii komórkowej wydaje się niezwykle ważny w perspektywie uświadomienia sobie skali szybkości innowacji w obrębie technologii mobilnych oraz inspirowanego przez te innowacje rozwoju i ewolucji całego rynku telekomunikacyjnego w XXI w. Owe poszczególne etapy transformacji technologicznej, stopniowo wnoszące współczesną telefonię mobilną na nowe poziomy zaawansowania, doprowadziły do uczynienia $z$ niej złożonej multimedialnej platformy, integrującej rozmowy bezprzewodowe, internet i łączność satelitarną. Uwarunkowania technologiczne wydają się mieć zasadnicze, a przynajmniej trudne do pominięcia znaczenie dla takich procesów określających wyłanianie się i rozwój współczesnych rynków telefonii komórkowej, jak przede wszystkim:

1) Przeobrażenia sektora telekomunikacyjnego - niemal wszędzie na świecie upowszechnianie się telefonii ruchomej prowadziło do znaczącego uszczuplania obszaru telefonii stacjonarnej jako wiodącego dotychczas segmentu rynków telekomunikacyjnych świata ${ }^{25}$. Telefonia komórkowa okazała się nie tylko skuteczną drogą do przezwyciężania zapóźnień i dystansów telekomunikacyjnych w wielu krajach świata, ale zasadniczo przejęła rolę głównego koła zamachowego prawie każdej krajowej telekomunikacji. Z kolei, wraz z udanym połączeniem telefonii mobilnej i internetu, telefony komórkowe zaczęły wypierać stacjonarne połączenia $\mathrm{z}$ internetem. Współcześnie, u progu trzeciej dekady XXIw. rynek telekomunikacyjny jest przede wszystkim definiowany w odniesieniu do branży telefonii komórkowej, przy wyraźnej marginalizacji tradycyjnej telekomunikacji stacjonarnej.

2) Powstanie nowych podmiotów i uformowanie się szeregu złożonych relacji i powiązań na rynku telefonii komórkowej - przed nadejściem ery cyfrowej rynek telefonii komórkowej stanowił swego rodzaju proste odzwierciedlenie rynku telefonii stacjonarnej, na którym funkcjonowały dwie grupy przedsiębiorstw - firmy operatorskie dysponujące odpowiednią infrastrukturą i dostarczające usługi łączności (tzw. operatorzy infrastrukturalni) oraz producenci sprzętu (aparatów telefonicznych, terminali, pozostałej infrastruktury). Od strony poda-

24 W.M. Maziarz, Strategiczne aspekty funkcjonowania operatorów na rynku usług telefonii komórkowej w Polsce, „Zeszyty Naukowe Zachodniopomorskiej Szkoły Biznesu. Firma i Rynek” nr 1, 2015, s. 43.

25 V. Kuusela, M. Callegaro, V. Vehovar, The Influence of Mobile Telephones on Telephone Surveys, [w:] Advances in telephone survey methodology, red. J.M. Lepkowski, C. Tucker, M. Brick et al., John Wiley \& Sons, New York 2007, s. 87-112. 
żowej rozwój technologii cyfrowej (szczególnie w połączeniu z internetem) oraz dyferencjacja usług bezprzewodowych doprowadziły do wyłonienia wielu nowych podmiotów, takich jak: a) operatorzy wirtualni, czyli operatorzy niedysponujący własną infrastrukturą, jednak świadczący usługi telefonii komórkowej pod własnymi markami w oparciu o sieci należące do operatorów infrastrukturalnych; b) właściciele treści (mediów) jako podmioty posiadające prawa własności intelektualnej (etykiet, znaków towarowych, franchisingu) do twórczych materiałów wysyłanych do klientów za pośrednictwem sieci; ich obecność to również efekt wzrostu regulacji w obrębie praw autorskich ukierunkowanych na treści przesylane za pośrednictwem internetu jako wirtualnej przestrzeni wymiany dóbr intelektualnych i twórczych; c) usługodawcy dostarczający wartości dodanej jako podmioty obsługujące innowacyjne usługi oferowane przez sieci. Podmioty takie mogą prowadzić także wsparcie rozliczeniowe lub wsparcie klienta w zakresie dostępu do mediów ${ }^{26}$.

3) Zmiana modeli biznesowych firm - dynamicznie rozwijające się technologie cyfrowe w obszarze łączności mobilnej doprowadziły nie tylko do sporych przetasowań w obrębie sposobów zarządzania i regulowania sektora telekomunikacyjnego na świecie, ale wywarły również ogromny wpływ na zmiany zachodzące w strukturach organizacyjnych przedsiębiorstw działających na rynku telekomunikacyjnym ${ }^{27}$. Samo zastąpienie elektromechanicznego systemu analogowego systemem cyfrowym wymusiło zmianę relacji pomiędzy firmami telekomunikacyjnymi a producentami sprzętu - nastąpiła separacja infrastruktury od dostaw usług oraz powiązanie w łańcuch rozdzielonych wcześniej etapów tworzenia informacji, pakietowania, dostarczania infrastruktury i sprzedaży terminali. Dostawcy usług zaczęli specjalizować się pionowo i geograficznie, dostarczając usługi na różnych poziomach sieci. Rozwijający się rynek wymuszał w ten sposób specjalizację, elastyczność ofert oraz koncentrację na wybranych rodzajach działalności w obrębie łańcucha dostaw. W efekcie prowadziło to również do znaczących zmian w strukturach organizacyjnych firm operatorskich, które zaczęły wyodrębniać osobne spółki, specjalizujące się najczęściej w jednej, wybranej sferze działalności ${ }^{28}$.

4) Przyspieszenie procesów liberalizacji i zła mania monopolu w obszarze telekomunikacji - postęp techniczny w obrębie telefonii komórkowej wraz z towarzyszącymi

26 L.F. Pau, The communications and information economy: issues, tariffs and economic research areas, „Journal of Economic Dynamic and Control" Vol. 26, No. 9-10, 2002, s. 1652-1653.

27 K.A. Eliassen, M. Sjøvaag, Introduction, [w:] European Telecommunications Liberalisation, red. K.A. Eliassen, M. Sjøvaag, Routledge, London 1999, s. xi.

28 P. Maskell, II. Esklinen, I. IJannibalsson, A. Mamberg, E. Vatne, op.cit., s. 155. 
mu równolegle decyzjami politycznymi i zmianami w prawodawstwie znacząco przyspieszył „naturalną śmierć” monopolu, który przez dekady określał funkcjonowanie sektora telekomunikacyjnego w zdecydowanej większości państw świata ${ }^{29}$. Nowa telefonia komórkowa, wyradzająca się niemal od początku jako technologiczny fenomen przekraczający granice państw, wymagała dla swego rozwoju nowych liberalnych uwarunkowań prawnych i politycznych, co było koniecznym warunkiem dalszego postępu technologicznego (zob. kolejny punkt).

5) Internacjonalizacja przedsiębiorstw telekomunikacyjnych - wysoki stopień technologicznego zaawansowania telefonii komórkowej, konieczność zaangażowania do jej wdrożenia ogromnych nakładów kapitałowych oraz fakt, że technologię tę rozwijano w kilku stosunkowo elitarnych ośrodkach w dużej mierze wpłynęły na to, iż otwieranie rynków telefonii komórkowej na całym świecie wymagało konieczności transferowania tej technologii z tych ekskluzywnych ośrodków (głównie ośrodek skandynawski, anglo-amerykański, japoński oraz do pewnego stopnia francuski i niemiecki) do państw pozostających poza tymi centrami. Transfer ten wy magał równiez zaangażowania finansowego i intelektualnego (wiedza menedżerska, know-how) ze strony najbardziej zaawansowanych przedsiębiorstw telekomunikacyjnych, które zyskiwały w ten sposób ogromne możliwości wyjścia poza swoje tradycyjne geograficzne obszary działalności i realizowania tym samym strategii globalnej ekspansji. Procesy te okazały się szczególnie doniosłe w kontekście konieczności budowania zaawansowanej infrastruktury w celu przyciągnięcia inwestycji w krajach słabo rozwiniętych oraz tych, które w latach 90. przechodziły transformację systemową ${ }^{30}$. Stąd też w krajach, do których telefonia komórkowa przychodziła $z$ zewnątrz, wymagało to przede wszystkim tworzenia pewnych wspólnych, ponadnarodowych form działalności w tej nowej branży, co korespondowało z politycznymi procesami liberalizacji i zmianami prawnymi, prowadzącymi do otwierania własnych rynków dla inwestorów $z$ zagranicy. W rezultacie firmy operatorskie $z$ krajów będących centrami rozwoju technologii mobilnej zwiększały swoje zaangażowanie w międzynarodowej działalności gospodarczej, przeobrażając się nierzadko w korporacje i koncerny o zasięgu światowym, natomiast rynek telefonii komórkowej stawał się w ten sposób jednym z najbardziej zglobalizowanych rynków XXIw.

29 P. Szkudlarek, Państwo jako podmiot ksztaltujący rynek telekomunikacji elektronicznej w Polsce, „Studia i Prace Wydziału Nauk Ekonomicznych i Zarządzania USz" t. 641, nr 22, 2011, s. 122-123.

30 B. Mody, L.-S. Tsui, The Changing Role of State, [w:] Telecommunications Politics: Ownership and Control of the Information Higway on Developing Countries, red. B. Mody, J.M. Bauer, J.D. Straubhaar, Lawrence Erlbaum Associates Inc., New York 1995, s. 179. 
6) Dynamizowanie procesów globalnej zmiany ekonomicznej - technologia komórkowa stała się narzędziem zmiany gospodarczej, przyczyniając się zasadniczo do przeobrażenia gospodarki XXIw. w układ złożonych i globalnych relacji ekonomicznych, charakteryzujących się znaczną marginalizacją tradycyjnych podziałów narodowych. Jeszcze silniejszy tego rodzaju efekt telefonia komórkowa wywierała $w$ połączeniu $z$ internetem, oferując mobilny dostęp do globalnej sieci w gospodarce, w której centralne znaczenie zaczęła posiadać informacja, wiedza i usługa. Innymi słowy, ewoluująca w stronę sieci internetowej telefonia komórkowa okazała się być nie tylko nowym at rakcyjnym wynalazkiem, czy tė̇ produktem/usługą numer jeden, ile sama stała się instrumentem transformacji globalnej i włączania gospodarek narodowych w procesy integracji ekonomicznej.

\section{Uwarunkowania polityczno-prawne}

Zasadniczym uwarunkowaniem politycznym, które okazało się nieodzowne dla budowy i szybkiej ekspansji globalnego rynku telefonii komórkowej, był bez wątpienia demontaż powojennego, dwubiegunowego układu sił politycznych na świecie. Procesy te zasadniczo zbiegły się z innym kluczowym uwarunkowaniem - bardzo silną na Zachodzie presją na prowadzenie neoliberalnej polityki gospodarczej, ze szczególnym uwzględnieniem konieczności odejścia od monopolu w sektorze telekomunikacyjnym $^{31}$. Przez prawie cały XXw. w większości państw świata usługi telekomunikacyjne były świadczone przez narodowych, najczęściej państwowych operatorów, utrzymujących monopolistyczną pozycję rynkową. Po II wojnie światowej w zachodniej ekonomii dominowało bowiem przekonanie o potrzebie utrzymywania pewnych dziedzin gospodarki pod kuratelą państwa, zapewniającego w ten sposób podstawowe usługi swoim obywatelom. Telekomunikację postrzegano dodatkowo jako dziedzinę strategicznego i infrastrukturalnego bezpieczeństwa państwa, które powinno chronić swój telekomunikacyjny monopo ${ }^{32}$. Ten ideologiczny klimat zaczął stopniowo zmieniać się w latach 80. wraz z zyskującą na sile popularnością idei neoliberalnych, stanowiących połączenie ekonomii neoklasycznej z teoriami

31 J.K. Ponder, E.N. Markova, Bridging the Eastern European Digital Divide: Significance of Mobile Telecommunications in Poland and Russia, „Communications \& Strategies” No. 45, 2002, s. 171; G. Goggin, Global Mobile Media, Routledge, New York 2016, s. 13.

32 A. Kuźnar, Proces liberalizacji międzynarodowego handlu ustugami w ramach WTO oraz jego skutki, "Zeszyty Naukowe Kolegium Gospodarki Światowej SGI" nr 15, 2004, s. 134. Z tych przyczyn przynajmniej częściowo rynki te byly słabiej zinternalizowane w porównaniu $z$ innymi branżami lat 70 . i 80 . ubiegłego stulecia. 
utrzymującymi, że interwencjonizm państwowy negatywnie wpływa na społeczno-gospodarczy rozwój krajów ${ }^{33}$. W Europie impulsu do zmian dostarczyły reformy wprowadzone przez rząd Margaret Thatcher w Wielkiej Brytanii, które w krótkiej perspektywie czasowej przyniosły szereg pozytywnych efektów dla pobudzenia gospodarki brytyjskiej. W prywatyzacji państwowych firm telekomunikacyjnych, liberalizacji oraz wprowadzeniu prawa umożliwiającego nabywanie licencji na świadczenie usług telekomunikacyjnych przez podmioty prywatne upatrywano nie tylko wywołania dobroczynnych skutków wprowadzenia konkurencji, ile także pewnej drogi przezwyciężania trudności finansowych państw poprzez zwiększanie ich przychodów budżetowych. Centralny wydaje się jednak neoliberalny paradygmat konkurencji - jego wdrożenie było widziane jako nieunikniona droga dla wzmocnienia realizacji funkcji użyteczności publicznej usług telekomunikacyjnych poprzez spadek cen i poprawę dostępności. Spore znaczenie przypisywano również związkom zachodzącym pomiędzy wolnym rynkiem a innowacyjnością, nieodzowną z punktu widzenia rozwoju technologicznego oraz wzrostu konkurencyjności gospodarki narodowej rozumianej jako całośćc $c^{34}$.

Sukces brytyjskich reform liberalnych bardzo szybko skłonił inne europejskie kraje do wdrażania programów prywatyzacyjnych. Od $1986 \mathrm{r}$. we Francji zaczęto realizować program prywatyzacji Jacques’a Chiraca. Na początku lat 90. podobne kroki podjęły Hiszpania i Włochy. Wydaje się, że jeszcze szybciej procesy te przebiegały poza Europą - już w latach 1987-1988 za około 80 mld USD sprzedano część narodowego operatora Japonii, Nippon Telegraph and Telephone ${ }^{35}$. W Stanach Zjednoczonych do prywatyzacji państwowego operatora AT\&T doszło już w 1982 r., kiedy korporacja została zmuszona do sprzedaży swoim konkurentom około dwudziestu regionalnych spółek, na których bazie wyłoniło się siedem prywatnych spółek operatorskich, działających na rynkach lokalnych ${ }^{36}$. Dynamicznie procesy te przebiegaty w krajach $\Lambda$ meryki Lacińskicj, odgrywając również fundamentalną rolę w procesie transformacji gospodarczej postsocjalistycznych krajów Europy Wschodniej.

Prywatyzację państwowych operatorów telekomunikacyjnych można uznać za pierwszą falę ogólniejszych procesów liberalizacji. Wkrótce procesy te objęly zmiany w kierunku demonopolizacji i otwarcia rynków telekomunikacyjnych dla konkurencji. Za ich początek można uznać przyjęcie i opublikowanie przez Komisję Europejskiej

33 J.P. Singh, Leapfrogging Development, State University of New York Press, Albany 1999, s. 12.

34 W.II. Melody, Telecom Reform: Progress and Prospects, „Telecommunications Policy” No. 23, 1999, s. 13.

35 V.G. Vartan, Market Place. Big Stock Sale by Japanese, „The New York Times” 9 July 1987.

36 B. Borkowska, Monopolizacja i demonopolizacja rynku telekomunikacji w USA, [w:] Mikroekonomia. Studia przypadków, red. B. Klimczak, A. Matysiak, Wydawnictwo AE im. Oskara Langego we Wroclawiu, Wrocław 2006, s. 107-117. 
Wspólnoty Gospodarczej tzw. Zielonej księgi (1987 r.), w której zawarto postulaty szybkiego i pełnego otwarcia rynku telekomunikacyjnego dla urządzeń końcowych, prawnego oddzielenia funkcji regulacyjnych od dotychczasowych operatorów narodowych, ustalenia warunków, na jakich nowe podmioty operatorskie mogą budować własne sieci i świadczyć usługi telekomunikacyjne, oraz rozwijania wspólnych standardów dla sieci/produktów/usług telekomunikacyjnych ${ }^{37}$. W ten sposób, poczynając od końca lat 80. ubiegłego wieku, w obrębie EWG rozpoczął się proces prawny, którego celem było zdemontowanie monopoli telekomunikacyjnych w państwach Wspólnoty dzięki stopniowemu pozbawianiu operatorów narodowych wyłączności w tej dziedzinie oraz tworzenia przestrzeni dla uruchomienia konkurencji (głównie poprzez wprowadzanie regulacji i formułowanie systemów przyznawania licencji na świadczenie usług telekomunikacyjnych nowym operatorom, zob. zwięzle podsumowanie reform i ich celów zamieszczone w tabeli 1). W Europie reformy te doprowadziły do całkowitego otwarcia rynków telekomunikacyjnych we wszystkich krajach UE, co nastąpiło wraz z początkiem $1998 \mathrm{r}$. W Stanach Zjednoczonych zaś prawo usuwające wszystkie ograniczenia dotyczące konkurencji oraz w pełni liberalizujące rynek amerykański zaczęło obowiązywać dwa lata wcześniej ${ }^{38}$.

Procesom tym towarzyszyło również zawarcie wielu międzynarodowych porozumień dotyczących regulowania światowego handlu usługami telekomunikacyjnymi. Jedną z najważniejszych takich umów było włączenie w 1997 r. podstawowych usług telekomunikacyjnych do Układu Ogólnego w sprawie Handlu Usługami (General Agreement on Trade in Service, GATS). Początkowo porozumienie to podpisało blisko 70 krajów świata, które zobowiązały się do stopniowego znoszenia barier w międzynarodowym handlu usługami telekomunikacyjnymi (obejmującymi w szczególności telefonię komórkową), poprzez ułatwienie transgranicznych dostaw tych usług, dopuszczanie do własnych rynków firm zagranicznych lub ich obecności handlowej na terenie państw-sygnatariuszy, w dalszej perspektywie czasowej zaś swobodną sprzedaż i odsprzedaż zagranicznym operatorom infrastruktury telekomunikacyjnej danego kraju ${ }^{39}$.

37 F. Kamiński, Rola państwa w rozwoju telekomunikacji - doświadczenie historyczne, „Telekomunikacja i Techniki Informacyjne" nr 3-4, 2003, s. 4-5.

38 W. Borucki, K. Szarzec, Nowa struktura rynku telekomunikacyjnego - nowe podmioty, nowe zachowania, „Telekomunikacja i Techniki Informacyjne” nr 3-4, 2001, s. 4.

39 E. Senunas, The 1997 GATS Agreement on Basic Telecommunications: A Triumph for Multilateralism or the Market, „Boston College Intellectual Property \& Technology Forum” No. 11, 1997, s. 2. 
Tabela 1. Główne reformy sektorów telekomunikacyjnych na świecie

\begin{tabular}{|c|c|}
\hline Reformy & Cele \\
\hline $\begin{array}{l}\text { Prywatyzacja narodowych } \\
\text { przedsiębiorstw } \\
\text { pocztowo-telekomunikacyjnych }\end{array}$ & $\begin{array}{l}\text { - przyciągnięcie inwestorów w celu sfinansowania infrastruktury telekomunikacyjnej } \\
\text { - zwiększenie efektywności sektora } \\
\text { - wprowadzenie nowych ustug } \\
\text { - uzyskanie przychodów do budżetu państwa z procesu prywatyzacji }\end{array}$ \\
\hline $\begin{array}{l}\text { Wprowadzenie licencji dla } \\
\text { konkurujących ze sobą } \\
\text { operatorów }\end{array}$ & $\begin{array}{l}\text { - rozszerzenie zakresu usług; wejście na nowe rynki } \\
\text { - zwiekkszenie efektywności sektora poprzez wprowadzenie konkurencji } \\
\text { - spadek cen, poprawa zakresu i podaży usług } \\
\text { - stymulowanie innowacji, wprowadzenie zaawansowanych usług } \\
\text { - uzyskanie przychodów do budżetu państwa z tytułu oplat licencyjnych }\end{array}$ \\
\hline $\begin{array}{l}\text { Wprowadzenie transparentnego } \\
\text { procesu regulacji }\end{array}$ & $\begin{array}{l}\text { - zwiekkszenie wiarygodności procesów przyznawania licencji i regulacji } \\
\text { - zwiększenie zaufania do organów regulacyjnych, przyciągnięcie inwestycji }\end{array}$ \\
\hline $\begin{array}{l}\text { Nakaz łączenia sieci oraz } \\
\text { uwolnienia usługi publicznej } \\
\text { sieci telefonicznej }\end{array}$ & $\begin{array}{l}\text { - zniesienie barier dla powstawania konkurencji } \\
\text { - stymulowanie konkurencji w dziedzinie zaawansowanych usług (np. internetu } \\
\text { szerokopasmowego) }\end{array}$ \\
\hline $\begin{array}{l}\text { Regulacja cenowa metodą } \\
\text { ustanowienia pulapów } \\
\text { cenowych }\end{array}$ & $\begin{array}{l}\text { - stwarzanie zachęt do efektywnej podaży usług przez przedsiębiorstwa dominujące } \\
\text { - uproszczenie regulacji cenowej w stosunku do modelu regulacji stopy zwrotu } \\
\text { z kapitału (ROR) } \\
\text { - zlikwidowanie opóźnienia regulacyjnego i zapewnienie dostosowań cen bez } \\
\text { zbędnej zwłoki }\end{array}$ \\
\hline $\begin{array}{l}\text { Ukierunkowane fundusze } \\
\text { powszechnego dostępu }\end{array}$ & $\begin{array}{l}\text { - zwiększenie efektywności polityki powszechności } \\
\text { - zastąpienie mniej przejrzystego i potencjalnie antykorupcyjnego subsydiowania } \\
\text { krzyżowego }\end{array}$ \\
\hline $\begin{array}{l}\text { Usunięcie barier w handlu } \\
\text { międzynarodowym }\end{array}$ & $\begin{array}{l}\text { - zwiekkszenie inwestycji w sektorze } \\
\text { - zwiększenie konkurencji na rynkach } \\
\text { - ulepszenie komunikacji globalnej }\end{array}$ \\
\hline
\end{tabular}

'̌ródło: A. Solek, Państwo na rynku ustug telekomunikacyjnych, [w:] Państwo a rynek we wspólczesnej gospodarce. Wybrane problemy, red. Z. Dach, Polskie Towarzystwo Ekonomiczne, Kraków 2008, s. 83-84.

Chcąc podsumować zasadnicze efekty liberalizacji rynków telekomunikacyjnych, najogólniej można przyjąć, że procesy te doprowadziły do ${ }^{40}$ :

1) erozji monopolistycznej siły operatorów narodowych dzięki dopuszczeniu na rynek alternatywnych, prywatnych podmiotów operatorskich; efekt ten, który można potraktować szerzej jako przejaw i istotę liberalizacji, sprzyjał również zmianie modeli biznesowych w sektorze telekomunikacji w kierunku dopasowania ich do praktyk rynkowych;

2) harmonizacji technicznych standardów w celu redukowania/usuwania barier pozataryfowych w handlu;

3) otwierania rynków narodowych dzięki udzielaniu międzynarodowym operatorom legalnych licencji dla niemal wszystkich typów zamówień publicznych; ten efekt również można wpisać w zbiór ogólniejszych przejawów procesów liberalizacji gospodarek na świecie;

40 P. Maskell, II. Eskelinen, I. Ilannibalsson, A. Mamberg, E. Vatne, op.cit., s. 157. 
4) wzrastającej separacji pomiędzy sferą świadczenia usług a obszarem regulacji, który przekazywano najczęściej odrębnym, tworzonym w tym celu podmiotom państwowym.

Demonopolizacja i prywatyzacja sektora telekomunikacji oraz zmiana stosunków handlowych w kierunku umiędzynarodowienia były prawdopodobnie najważniejszymi czynnikami tworzącymi warunki do szybkiego rozwoju rynków telefonii komórkowej na świecie oraz rozwoju i dalszej ewolucji samej, niezwykle wymagającej i zaawansowanej technologii mobilnej. Należałoby tu wskazać m.in. na takie efekty, jak:

1) Uruchomienie przepływu kapitału i inwestycji - procesy prywatyzacji i liberalizacji pozwoliły na włączenie do gry rynkowej szeregu rozmaitych podmiotów prywatnych, tworząc warunki sprzyjające inwestycjom. Inwestycje te okazały się mieć fundamentalne znaczenie szczególnie dla krajów słabiej rozwiniętych, nieposiadających kapitału koniecznego do otwarcia rynku. Poza tym niemal od samego początku branża telefonii komórkowej została włączona w przestrzeń zmienności właścicielskiej, charakterystycznej dla globalizującego się biznesu. Kwestie własności operatorów komórkowych przestały być również domeną tylko i wyłącznie przedsiębiorst w branżowych - udziałami i akcjami operatorów komórkowych dość szybko zaczęły interesować się podmioty spoza branży, nierzadko zajmujące się tylko obrotem finansowym, co w efekcie istotnie wpłynęło na rozwój światowych rynków kapitałowych.

2) Wzrost innowacyjności - przełamanie tradycyjnych barier prawnych w obszarze telekomunikacji niewątpliwie ułatwiało międzynarodową komunikację w zakresie badań, projektowania i wdrażania innowacji oraz wyznaczania kierunków dalszego rozwoju technologii mobilnych. Przyczyniło się to w dużej mierze do intensyfikacji procesów konwergencji i łączenia rynku telekomunikacyjnego $z$ rynkiem informatycznym, medialnym oraz usług i technik. W tym sensie liberalna polityka światowa oraz ustawodawstwo tworzyło podatny grunt dla podtrzymywania aktualności, „świeżości” i atrakcyjności telefonii komórkowej jako jednej z najbardziej innowacyjnych branż XXIw.

3) Uruchomienie konkurencji globalnej - dzięki wpływowi, jaki sama telefonia komórkowa wywarła na przyspieszenie procesów liberalizacji i zniesienie tradycyjnych granic handlowych w obszarze telekomunikacji, niemal wszędzie na świecie te nowe masowe rynki rozwijały się jako jedne $z$ najbardziej zinternalizowanych rynków światowych. Większość tych rynków wyłoniła się bowiem w efekcie importu technologii, kapitału i wiedzy z kilku światowych i wysoce ekskluzywnych ośrodków rozwoju technologii mobilnej, uruchamiając procesy budowy wielkich ponadpaństwowych korporacji telekomunikacyjnych. 
W rezultacie rynki te stały się swego rodzaju rzeczywistym i praktycznie realizowanym wyrazem nowej ekonomii, opartej zasadniczo na wzorach globalnej konkurencji, stanowiącej jeden z fundamentalnych wyznaczników światowego ładu gospodarczego w XXIw.

\section{Podsumowanie}

Rynki telefonii komórkowej można uznać za jedne $z$ największych fenomenów gospodarki przełomu XX i XXIw. Do tej pory uchodzą one za jedne z najbardziej wpływowych i lukratywnych rynków świata. Ich wyłonienie się i dalszy rozwój na świecie to efekt interakcji wielu różnych czynników. Niemniej jednak kluczowe znaczenie mógłby tu mieć przede wszystkim często pomijany w opisach i analizach rozwoju rynku postęp techniczny oraz korespondujące $z$ nim zmiany polityczne i prawne związane z procesami liberalizacji światowego sektora telekomunikacyjnego. Oba te w dużej mierze historyczne już uwarunkowania wydają się być ze sobą ściśle powiązane. Dynamiczny i szybki rozwój technologii mobilnej oraz wprowadzanie jej na rynki masowe zasadniczo zbiegły się z silnym naciskiem na wdrażanie neoliberalnej polityki gospodarczej, która wymagała również odejścia od monopolu w sektorze telekomunikacyjnym. I chociaż teza ta może wydać się dyskusyjna, postęp techniczny w zakresie telefonii komórkowej mógł nicjako przyspieszać przebiegającą już w tym czasie demonopolizację sektora telekomunikacyjnego. W szczególności dynamicznie rozwijające się technologie bezprzewodowej łączności cyfrowej mogą zostać uznane za ważny bodziec dla zmiany sposobów zarządzania i regulowania sektora telekomunikacyjnego na świecie, co wywarło również znaczący wpływ na zmiany w sposobach zarządzania oraz $w$ strukturze organizacyjnej firm operatorskich i innych aktorów współtworzących podażową stronę rynku telekomunikacyjnego. Z drugiej zaś strony międzynarodowa i relatywnie skoordynowana zmiana warunków prawnych okazała się prawdopodobnie fundamentalna dla dalszej technologicznej ewolucji w obszarze połączeń bezprzewodowych.

Liberalizacja sektora telekomunikacyjnego korespondująca $z$ ewolucją technologii bezprzewodowych to również trudny do pominięcia impuls wyłaniania się nowego wzoru relacji gospodarczych na świecie z centralną rolą globalnej konkurencji. Handel sprzętem i usługami telekomunikacyjnymi po raz pierwszy został umieszczony w wielostronnym środowisku, przechodząc ze świata stosunków „jeden z jednym” do świata stosunków „wielu $z$ wieloma”. W rezultacie przesunięcie to osłabiło rolę handlu narodowego, gdzie relacje gospodarcze przebiegają pomiędzy narodami, 
a na znaczeniu zyskiwać zaczęły podmioty prywatne, działające ponad tradycyjnymi granicami narodowymi. Stała interakcja zachodząca pomiędzy technologią i procesami liberalizacji przyczyniła się w ten sposób do wyłonienia się nowych wyznaczników rozwoju całego sektora telekomunikacyjnego, takich jak: konkurencyjność, implementacja nowych technik i konwergencja usług telekomunikacyjnych, popyt konsumentów na usługi, zróżnicowanie podmiotów i specjalizacja relacji zachodzących na rynku telekomunikacyjnym (ze szczególną rolą, jaką odegrała tu branża telefonii komórkowej), w końcu zaś przyspieszenie procesów samej globalizacji.

\section{Literatura}

Billström O., Cederquist L., Ewerbring M., Sandegren G., Uddenfeldt J., Fifty years with mobile phones. From novelty to no. 1 consumer product, „Ericsson Review” No. 3, 2006.

Borkowska B., Monopolizacja i demonopolizacja rynku telekomunikacji w USA, [w:] Mikroekonomia. Studia przypadków, red. B. Klimczak, $\Lambda$. Matysiak, Wydawnictwo AE im. Oskara Langego we Wroclawiu, Wroclaw 2006.

Borucki W., Szarzec K., Nowa struktura rynku telekomunikacyjnego - nowe podmioty, nowe zachowania, „Telekomunikacja i Techniki Informacyjne” nr 34, 2001.

Burbank J.L., Andrusenko J., Everett J.S., Kasch W.T.M., Wireless Networking. Understanding Internetworking Challenges, John Wiley \& Sons, New York 2013.

Eliassen K.A., Sjøvaag M., Introduction, [w:] European Telecommunications Liberalisation, red. K.A. Eliassen, M. Sjøvaag, Routledge, London 1999.

Ellis S.R., Mobile Standards, [w:] Mobile Devices. Tools and technologies, red. L. Collins, S.R. Ellis, CRC Press, Boca Raton 2015.

Evolution and Standarization of Mobile Communications Technology, red. D.B. Seo, IGI Global, Hershey 2013.

Goggin G., Global Mobile Media, Routledge, New York 2016, s. 13.

Guga D., Technologia GSM jako platforma usług WWW i aplikacji internetowych-właściwości rozwiazań m-commerce, „Acta Universitatis Lodziensis” nr 167, 2003, S. „Folia Oeconomica".

Hebert M., Pang K., Chien-Ling W., Sou R., Kadiyala R., $3 G$ Telecommunications: Innovative Designs of Cellular Phones, [w:] Financing Technology Innovation, red. G. Shahi, J. Greco, GBI Books, Los Angeles 2008.

Kamiński F., Rola państwa w rozwoju telekomunikacji - doświadczenie historyczne, „Telekomunikacja i Techniki Informacyjne" nr 3-4, 2003.

Karbowniczek M., Nowe technologie w sieciach telefonii komórkowej, „Elektronika Praktyczna" nr 2, 2014. 
Kuusela V., Callegaro M., Vehovar V., The Influence of Mobile Telephones on Telephone Surveys, [w:] Advances in telephone survey methodology, red. J.M. Lepkowski, C. Tucker, M. Brick et al., John Wiley \& Sons, New York 2007.

Kuźnar A., Proces liberalizacji międzynarodowego handlu ustugami w ramach WTO oraz jego skutki, „Zeszyty Naukowe Kolegium Gospodarki Światowej SGII” nr 15, 2004.

Long Term Evolution (LTE). Kolejny krok w ewolucji systemów telefonii komórkowej, Prezes Urzędu Komunikacji Elektronicznej, Warszawa, maj 2010.

Maskell P., Eskelinen H., Hannibalsson I., Mamberg A., Vatne E., Competitiveness, Localised Learning and Regional Development. Specialization and prosperity in small open economies, Routledge, New York 2002.

Maziarz W.M., Strategiczne aspekty funkcjonowania operatorów na rynku ustug telefonii komórkowej w Polsce, „Zeszyty Naukowe Zachodniopomorskiej Szkoły Biznesu. Firma i Rynek" nr 1, 2015.

Melody W.H., Telecom Reform: Progress and Prospects, „Telecommunications Policy” No. 23, 1999.

Mody B., Tsui L.-S., The Changing Role of State, [w:] Telecommunications Politics: Ownership and Control of the Information Higway on Developing Countries, red. B. Mody, J.M. Bauer, J.D. Straubhaar, Lawrence Erlbaum Associates Inc., New York 1995.

Pau L.F., The communications and information economy: issues, tariffs and economic research areas, „Journal of Economic Dynamic and Control” Vol. 26, No. 9-10, 2002.

Ponder J.K., Markova E.N., Bridging the Eastern European Digital Divide: Significance of Mobile Telecommunications in Poland and Russia, "Communications \& Strategies” No. $45,2002$.

Sathi A., Engaging Customers Using Big Data. How Marketing Analytics in Transforming Business, Palgrave Macmillan, New York 2014.

Sarwar M., Soomro T.R., Impact of Smartphone's on Society, „European Journal of Scientific Research" No. 2, 2013.

Senunas E., The 1997 GATS Agreement on Basic Telecommunications: A Triumph for Multilateralism or the Market, „Boston College Intellectual Property \& Technology Forum” No. 11, 1997.

Singh J.P., Leapfrogging Development, State University of New York Press, Albany 1999.

Szkudlarek P., Państwo jako podmiot ksztaltujacy rynek telekomunikacji elektronicznej w Polsce, „Studia i Prace Wydziału Nauk Ekonomicznych i Zarządzania USz” t. 641, nr 22, 2011.

Vartan V.G., Market Place. Big Stock Sale by Japanese, „The New York Times” 9 lipca 1987. WAP - nowy wymiar telefonii komórkowej, „Magazyn Elektroniki Użytkowej” nr 7, 2000.

Waverman L., Meschi M., Fuss M., The Impact of Telecoms on Economic Growth in Developing Countries, ,Working Paper the Vodafone Policy” No. 3, 2005. 
Wereda W., Czynniki wpływające na rozwój rynku telefonii komórkowej w Polsce, „Zeszyty Naukowe Akademii Podlaskiej” nr 82, 2009, S. „Administracja i Zarządzanie”.

http://data.un.org/

http://www.itu.int/

\section{Historical Causes of Creation and Development of Mobile Phone Markets in the 20th and 21st Centuries}

The article is focused on the presentation and analysis of two historical determinants that probably had the greatest impact on the rise and development of global mobile phone markets. On the one hand, this is the technical development of wireless telephony, which can also be seen as a space that provided a major impulse for political and legal changes in telecommunications. On the other hand, these political and legal changes associated with processes of liberalization in the world telecommunications have been described as the second fundamental factor.

Keywords: mobile phone market, mobile phone technology, telecommunications, liberalization

\section{Les conditions historiques d'établissement et de développement des marchés de la téléphonie mobile auX XXe et XXI ${ }^{\mathrm{e}}$ siècles}

L'objectif de ce texte est de montrer et d'analyser deux conditions historiques clés qui ont probablement influencé dans la plus grande mesure l'établissement et le développement des marchés mondiaux de la téléphonie mobile. D’une part, ces conditions comprennent les progrès techniques dans le domaine de la téléphonie cellulaire qui peuvent également être interprétés comme un espace donnant une impulsion importante aux changements politico-juridiques dans le domaine des télécommunications. D’autre part, les changements politico-juridiques eux-mêmes ont été également décrits en termes de conditions fondamentales. Ils se présentent principalement dans les processus de libéralisation du secteur des télécommunications dans le monde.

Mots-clés: marché de la téléphonie mobile, technologie mobile, télécommunications, libéralisation 


\section{Исторические условия возникновения и развития рынков мобильной связи в XX-XXI веках}

Цель статьи - указать и проапализировать две ключевые исторические детерминанты, которые в наибольшей степени способствовали появлениго и развитию глобалыных рынков мобилыюй телефонии. С одной стороны, это техническое развитие в области беспроводной телефонии, что можно также рассматривать как важный стимул для политических и правовых изменений в области телекоммуникаций. С другой стороны, как второй основной фактор были восприняты политические и правовые изменения, связапне с процессами либерализации телекоммуникаций.

Ключевые слова: рынок мобильной связи, мобильные технологии, телекоммуникации, либерализация 